\title{
Low-velocity impact response of 3D polyurethane resin composites reinforced with spacer fabrics
}

\section{REZUMAT - ABSTRACT}

\section{Răspunsul impactului la viteză redusă al compozitelor din rășină poliuretanică 3D armate cu structurl tricotate}

\begin{abstract}
Acest studiu a urmărit să investigheze răspunsul la viteză redusă a compozitelor pe bază de poliuretan. Trei structuri tricotate, produse pe o mașină de tricotat din urzeală cu două fonturi, au fost utilizate ca element de armare. Două micro-baloane au fost adăugate și în compozite. Un nou tip de rășină numită rășină poliuretanică a fost implicată în fabricarea compozitelor. În consecință, comportamentele de impact ale compozitelor au fost evaluate corespunzător la viteza de impact de $1 \mathrm{~m} / \mathrm{s}$ și, respectiv, $2 \mathrm{~m} / \mathrm{s}$. Rezultatele obținute ilustrează faptul că aceste compozite posedă proprietăți excelente de impact la viteză redusă și că proprietățile de rezistență la impact sunt semnificativ afectate de structurile de suprafață ale tricoturilor și de tipurile de micro-balon, indicând faptul că absorbția lor de energie la impact poate fi adaptată pentru a satisface cerințele de utilizare finală, prin modificarea parametrilor structurali.

Cuvinte-cheie: răspuns la viteză redusă, rășină poliuretanică, structuri Spacer tricotate din urzeală, micro-balon
\end{abstract}

Low-velocity impact response of 3D polyurethane resin composites reinforced with spacer fabrics

This research aimed to investigate the low-velocity response of polyurethane-based composites. Three warp-knitted spacer fabrics produced on a double-needle bar warp knitting machine by vary different surface structures were used as the reinforcement element. Two Micro-balloons were added into the composites as well. A new type of resin named polyurethane resin was involved for fabricating the composites. Accordingly, the impact behaviors of composites were evaluated properly under the impact velocity of $1 \mathrm{~m} / \mathrm{s}$ and $2 \mathrm{~m} / \mathrm{s}$, respectively. The findings obtained illustrate that the composites possess excellent low-velocity impact properties and the impact resistance capacities are significantly affected by the fabric surface structures and the types of Micro-balloon, indicating that their impact energy absorbability can be tailored to meet the specific end-use requirements by varying the structural parameters.

Keywords: low-velocity response, polyurethane resin, warp-knitted spacerfabrics, Micro-balloon

\section{INTRODUCTION}

Low-velocity response, from the viewof designing, is of particular important criterion inthe use of composite structures [1]. Nowadays, a series of investigations on 3D-textile structures in terms of the lowvelocity response and theoretical analyses have been conducted recently. Composites with integrated 3D structure offer the great potential to be used in impact-resistance applications, since they combine low weight with high impact resistance abilities and their delamination resistant abilities are also preferable. The most widely used 3D-textile materials are spacer fabricsconsisting of two separate layers connected by spacer yarns. The surface layers could obtain various structuresdepending on different applications. Moreover, the spacer yarns place at various angles and distances from the outer layers.

The effect of hybridization on the low-velocity impact behavior of woven carbon/basalt fiber-reinforced intra-ply hybrid composites was investigated by Shishevan et al., they found that the impact performance of homogenous composites is improved by hybridization, i.e., the maximum force and absorbed impact energy are increased by the addition of basalt fibers as a complementary element to the structure of composites [2]. He et al. investigated the low-velocity impact response and post-impact flexural performance of hybrid sandwich structures with carbon fibre-reinforced polymer (CFRP) face sheets and aluminium alloy corrugated cores [3]. The findings obtained that the damage depends on the impact energy and impact location. Meanwhile, the residual flexural strength decreases significantly when the impact energy is lower than $10 \mathrm{~J}$, after that there is a slight reduction with a further increase in the impact energy. Zhi et al. fabricated eight different kinds of warp-knitted spacer fabric reinforced syntactic foam composites, including different fabric surface layer structures, different spacer yarn diameters and inclination-angles, different Micro-balloon types and contents [4]. The influence of warp-knitted spacer fabric and hollow glass Micro-balloon parameters on the impact performance of composites was conducted. The results demonstrated that the surface layer structure, inclination-angle of the spacer yarn and the volume fraction and type of Micro-balloon have a significant influence on the low-impact performance of composites. Studies on impact behaviors of composites based on 3D warp-knitted fabrics have also been investigated recently [5-7]. Some effect factors, that is, cross-thread density, fineness of yarns and structure of face of fabrics, as well as thickness of fabrics, 
on the impact response have been extensively discussed.

The present work reports the low-velocity impact of 3D spacer composites based on polyurethane resin, which obtains better strength and toughness properties. Moreover, the manufacturing process for polyurethane resin is simpler than that of traditional resin composites. With an attempt to discuss the effect of structural parameterson the low-velocity impact properties of composites, three types of warp-knitted spacer fabrics with different outer layer structure were used to fabricate the composites. Meanwhile, two kinds of hollow glass Micro-balloon were involved to investigate the influence on the addition of Micro-balloon as a complementary element. It is expected that a regular pattern for tailoring the composites with favorable low-velocity impact response could be found from this study.

\section{MATERIALS AND EXPERIMENTS}

\section{Samples}

\section{Warp-knitted spacer fabrics}

Three types of warp-knitted spacer fabricsused in this work have been produced (Wuyang CO. LTD, Jiangsu, China). The PET monofilament of $0.2 \mathrm{~mm}$ in diameter was used for spacer yarns, while 300D/96F PET multifilament were used as surface layer yarns. The surface structures of spacer fabrics are Chain+ Inlay, Rhombic and Hexagonal Mesh, as shown in figure 1. It can be revealed that the size of surface's mesh is successively increased. All the samples were heat-set at $180^{\circ} \mathrm{C}$ for $3 \mathrm{~min}$. However, it should be mentioned thatdespite the same setting of warping machine, actual thickness of three samples were all near $7.4 \mathrm{~mm}$, thus, it can be considered that the thickness of these fabrics were close to each other.

\section{Preparation of the composites}

The composites were produced by impregnating the warp-knitted spacer fabrics with a polyurethane resin (BASF, PuDong Site, Shanghai, China), consisting of a mix of isocyanate and polyol, in a $49.8 / 100$ isocyanate-polyol mixing ratio (by weight). Two types of hollow glass Micro-balloon named S15 and im16k were involved in this study. The hollow glass Microballoon was mixed with polyol by speed-mixer machine firstly, and then the Micro-balloon-polyol mixture mixed with isocyanate. The important properties of this polyurethane resinand two hollow glass Micro-balloon are listed in table 1. Production of the composite samples was carried out in light VARTM machine [8] in order to keep the 3D structure from being compressed. After filling, all the specimens were placed for 8 hours at $110^{\circ}$ temperature, until the polyurethane resin was stable. The nine types of polyurethane-based composites fabricated were provided in table 2.

\section{Impact tests}

Impact properties of the composites were evaluated using an Instron Dynatup 9250HV, and the test was

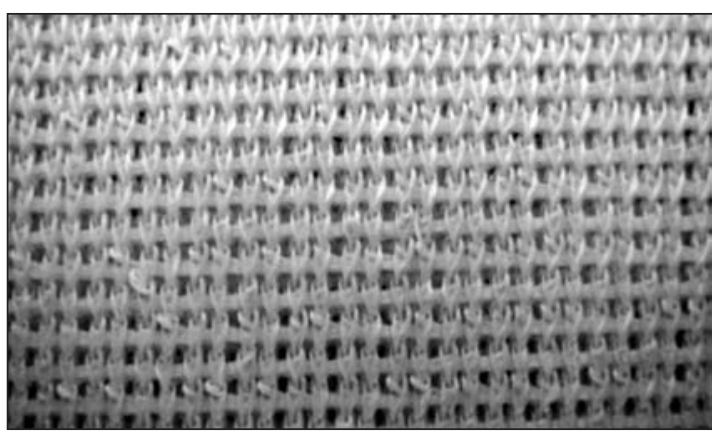

a

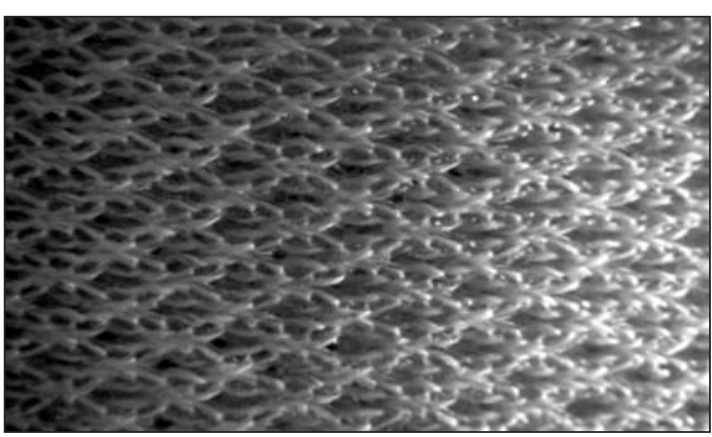

b

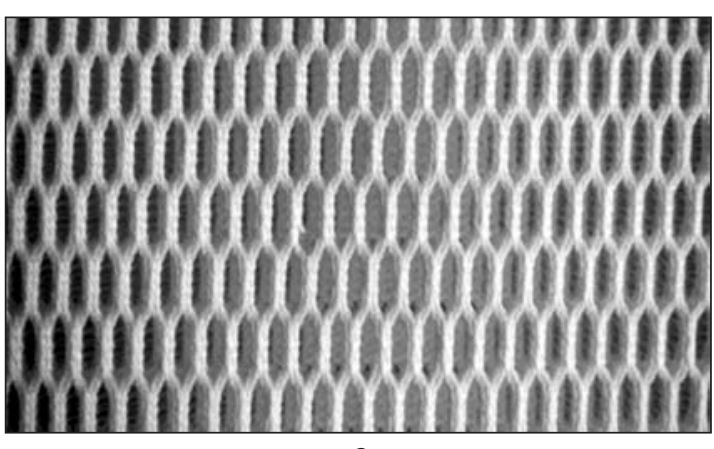

Fig. 1. The surface layer structures: $a-C h a i n+I n l a y ;$ $b$ - Rhombic; $a$ - Hexagonal Mesh

done at $23^{\circ} \mathrm{C}$ and $65 \%$ relative humidity according to ASTM 7136 test standard, as shown in figure 2. An impactor having diameter of $12.7 \mathrm{~mm}$ with a hemispherical tip was used to hit against the face of specimens $(100 \mathrm{~mm} \times 100 \mathrm{~mm})$. The weight of the impactor is $11.2 \mathrm{~kg}$. The initial velocity can be given which can be calculated in incident impact energy by

Table 1

\begin{tabular}{|c|c|c|c|}
\hline \multicolumn{4}{|c|}{$\begin{array}{l}\text { PROPERTIES OF POLYURETHANE RESIN AND } \\
\text { MICRO-BALLOON }\end{array}$} \\
\hline \multicolumn{2}{|c|}{ Title } & Property & Values \\
\hline \multirow{6}{*}{\multicolumn{2}{|c|}{$\begin{array}{l}\text { Polyurethane } \\
\text { resin }\end{array}$}} & Tensile strength (MPa) & 62.6 \\
\hline & & Tensile modulus $\left(\mathrm{N} / \mathrm{mm}^{2}\right)$ & 2113 \\
\hline & & Strain at break (\%) & 13.7 \\
\hline & & Flexural strength (MPa) & 83.3 \\
\hline & & Flexural modulus (MPa) & 1950 \\
\hline & & Impact strength $\left(\mathrm{kJ} / \mathrm{m}^{2}\right)$ & 116.9 \\
\hline \multirow{4}{*}{$\begin{array}{l}\text { Micro-bal- } \\
\text { loon }\end{array}$} & S15 & \multirow{2}{*}{ Young's modulus (MPa) } & 2.07 \\
\hline & im16k & & 113.7 \\
\hline & $\mathrm{S} 15$ & \multirow{2}{*}{ Diameter $(\mu \mathrm{m})$} & 55 \\
\hline & im16k & & 20 \\
\hline
\end{tabular}

industmoia textillă 


\begin{tabular}{|c|c|c|c|}
\hline \multicolumn{4}{|c|}{ DETAILS OF POLYURETHANE RESIN COMPOSITES } \\
\hline Code & $\begin{array}{c}\text { The surface } \\
\text { of spacer } \\
\text { fabrics }\end{array}$ & $\begin{array}{c}\text { The type of } \\
\text { spacer fabrics } \\
\text { Micro-balloon }\end{array}$ & $\begin{array}{c}\text { The content of } \\
\text { Micro-balloon } \\
\text { (by weight) }\end{array}$ \\
\hline S1 & Chain+lnlay & None & None \\
\hline S2 & Rhombic & None & None \\
\hline S3 & $\begin{array}{c}\text { Hexagonal } \\
\text { Mesh }\end{array}$ & None & None \\
\hline S4 & $\begin{array}{c}\text { Polyurethane } \\
\text { resinwithout } \\
\text { spacer fabrics }\end{array}$ & None & None \\
\hline S5 & Rhombic & S15 & $1 \%$ \\
\hline S6 & Rhombic & S15 & $3 \%$ \\
\hline S7 & Rhombic & im16k & $1 \%$ \\
\hline S8 & Rhombic & im16k & $3 \%$ \\
\hline
\end{tabular}

Kinetic energy formula. The incident impact velocity used for work was $1 \mathrm{~m} / \mathrm{s}$ and $2 \mathrm{~m} / \mathrm{s}$, respectively. For each composite, three samples were tested and the ultimate result was the average of the three tests.

\section{RESULTS AND DISCUSSION}

\section{Impact response of composites}

The relationship between force and displacement at different surface structures under different impact velocities $(1 \mathrm{~m} / \mathrm{s}$ and $2 \mathrm{~m} / \mathrm{s})$ is shown in figure 3 , $a$ and $b$, respectively. It can be seen that the force is bound to change with the changes of surface structures. Moreover, it is revealed that the composites reinforced with spacer fabrics obtain higher strength than that of composites without spacer fabrics, indicating that the spacer fabrics can significant improve the impact resistance performance of composites. Referring to figure 3 , $a$, it is observed that composites S2 obtains slightly higher maximum force value than the others. And the differencein maximum force values betweenthree composites (S1\&S2) is not significance. This is due to the fact that the different surface structures obtain different arrangement of spacer yarn, resulting in different impact resistance capacities when suffering impact load. The spacer yarn inclination angle for Chain+Inlay is nearly vertical and the spacer yarn inclination anglefor Hexagonal Mesh is too small, while the spacer yarn inclination angle for rhombic mesh is $69.32^{\circ}$ [9], indicating that the rhombic mesh structure has better stability and is more suitable for absorbing higher energy. However, it is evident that the displacement at peak force for composites S1, S2 and S3 is different. According to figure 1, it can be found that the opener outer layer structure moves the peak force to higher displacement range, resulting in an increase of loading stage which means in this region, a nearly constant stress is obtained as the displacement is increased.

It is demonstrated that the opener surface structures can absorb more impact energy by undergoing selfdeformation before they break. This is attributed to the opener surface structure used in the composite,

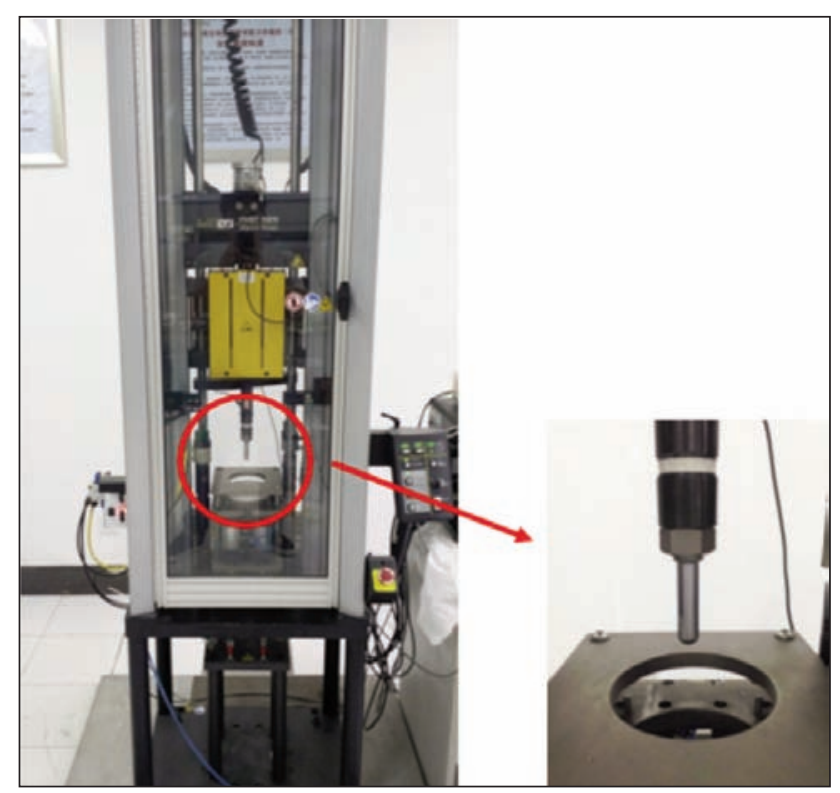

Fig. 2. The Impact instrument

leading to lower deformation resistance capability. From the force-displacement curves, it can be recognized that there exists a sudden drop at the initial stage, with the increasing of the impact velocity, a new initial peak force appears, which is even higher than the first one. It is because the resin matrix was broken when the impactor conducted the composites at the beginning of stage, which results in the force's drop. With the increasing of impact velocity, the fabric-resin composites exhibited higher strength become the main contributor to the impact energy absorbing, which leads to the increasing of force value.

For the composites under the impact velocity of $2 \mathrm{~m} / \mathrm{s}$ (figure $3, b$ ), the same tendency is observed in the force-displacement curves. However, the loading stage for composites under the impact velocity of $2 \mathrm{~m} / \mathrm{s}$ is larger than that of composites under the impact velocity of $1 \mathrm{~m} / \mathrm{s}$. It is because the larger impact velocity, the lager deformation (longer loading stage) is needed to absorb impact energy. It is demonstrated that the polyurethane resin has superior toughness as compared to the traditional epoxy resin.

\section{Impact response of composites with Micro-balloon}

The impact responses of composites with Micro-balloon under the impact velocity of $1 \mathrm{~m} / \mathrm{sare}$ shown in the figure 4, a, from which the effect of Micro-balloon's content and type can be clearly observed. For S5 and $\mathrm{S} 6$, the impact resistance capacities increase as the Micro-balloon's content increases. However, the result for S7 and S8 is reverse. This phenomenon is due to the diameter of Micro-balloon. The diameter of Microballoon used for S5 and S6 is much larger than that of S7 and S8. Although the smaller Micro-balloon (table 1) has higher Young's modulus, the Micro-balloon is not the main contributor to absorb impact energy on the small-deformation condition. It means that the main absorbers of the impact load are resin and fabrics when the impact velocity is $1 \mathrm{~m} / \mathrm{s}$. For this 


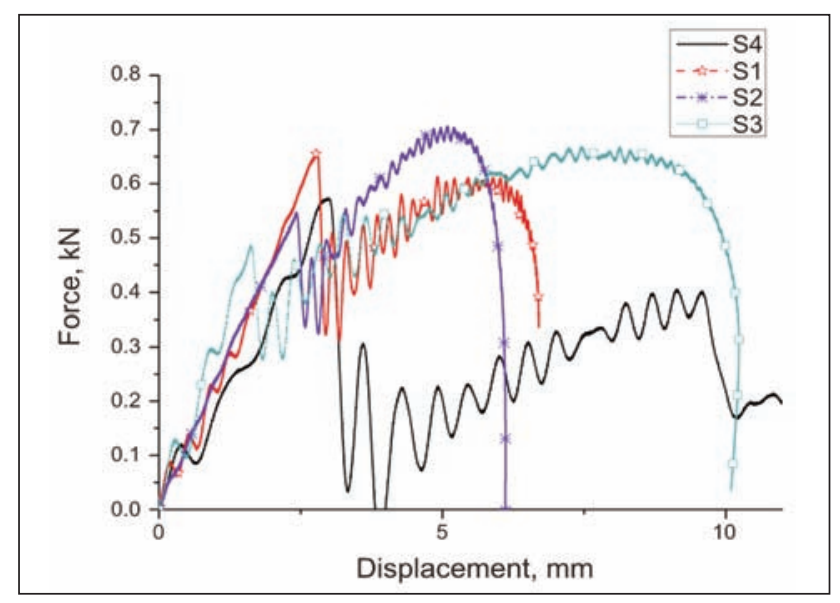

a

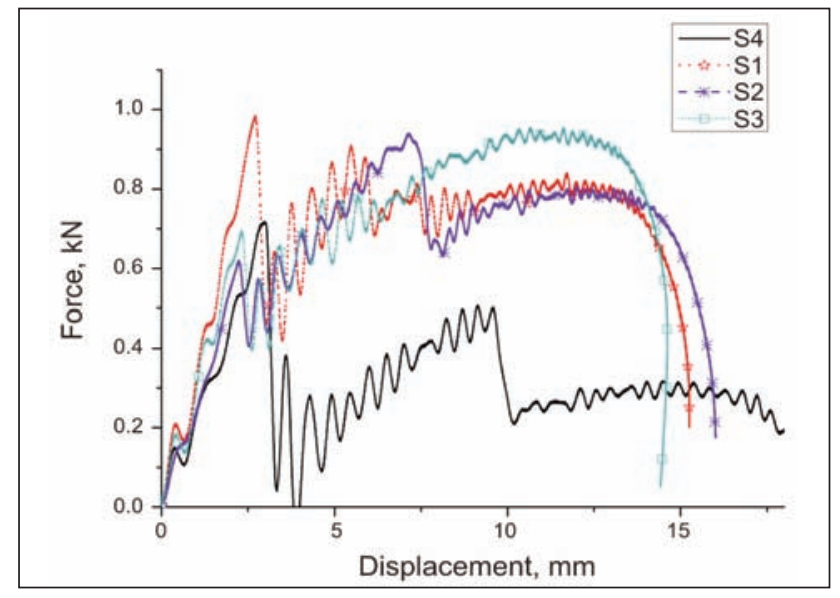

b

Fig. 3. The impact response of composites: $a-$ the impact velocity of $1 \mathrm{~m} / \mathrm{s} ; b$ - the impact velocity of $2 \mathrm{~m} / \mathrm{s}$

reason, the effect of Micro-balloon's strength is not clear on the small deformation condition. However, when the impact load reaches the internal parts of composites, the Micro-balloon can change the propagation paths of the impact load happened in the composites according to Law of minimum resistance. It indicates that impact load in the composites will propagate along the surface of Micro-balloon without breaking it. In that case, the larger diameter the Micro-balloon has, the longer propagation paths obtained. According to the law of mass action, the propagation path and energy consumption of impact load will be changed with the changes of quality of the composites per unit area. Therefore, the composites with lager Micro-balloon diameter exhibit varied impact resistance performance.

For the composites under the impact velocity of $2 \mathrm{~m} / \mathrm{s}$ (figure $4, b$ ), the same tendency is observed in the force-displacement curves. However, the impact resistance performance for $\mathrm{S} 7$ is better than S8, which is quite different from the condition of impact velocity of $1 \mathrm{~m} / \mathrm{s}$. It is attributed that when the composite were further compressed (lager deformation), the Micro-balloon becomes the contributor of impact load. In this circumstance, the higher content of Micro-balloon can obviously improve the impact resistance capacities of composites. It is need to point out
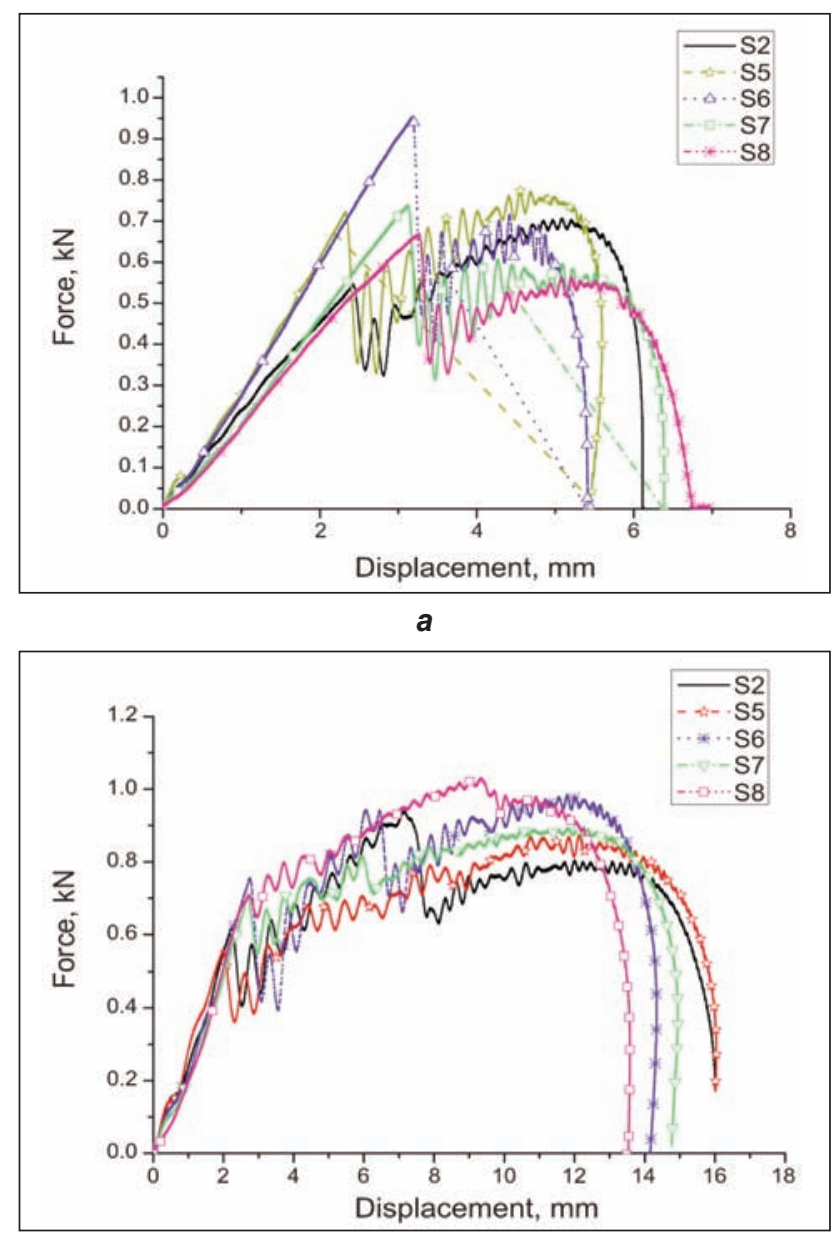

b

Fig. 4. The impact response of composites with Micro-balloon: $a$ - the impact velocity of $1 \mathrm{~m} / \mathrm{s} ; b$ - the impact velocity of $2 \mathrm{~m} / \mathrm{s}$

that for the corresponding composites with and without Micro-balloon, the impact resistance properties of composites are different. The composites with Microballoon exhibit superior impact resistance performance as compared to the composites without composites, illustrating that the Micro-balloon can improve the composites' impact resistance significantly.

Figure 5 shows SEM images of polyurethane composites after suffering impact load. Referring to figure 5 , $a$, it can be found that when suffering impact load, in despite of some cracked, broken, and extruded Micro-balloons, the others are intact. It is demonstrated that the impact load happened in the composites propagates along the surface of Micro-balloon without breaking it. Figure $5, b$ shows the SEM image of broken condition for polyurethane resin. The step ladder failure can be seen obviously. It is due to the fact that the composites reinforced with fabrics and Micro-balloon can change the propagation paths of impact load which results in repeatedly broken in the internal parts of composites, leading to absorb more impact energy. It is necessary to highlight that the stepladder failure is partly responsible for the fluctuation obtained in the force-displacement curves of composites. 


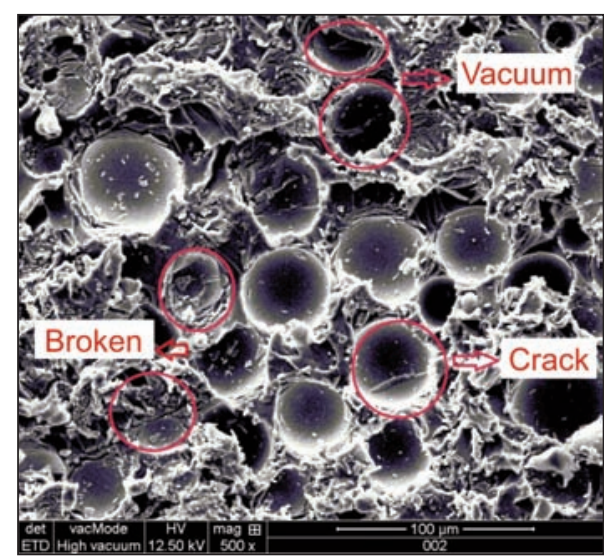

a

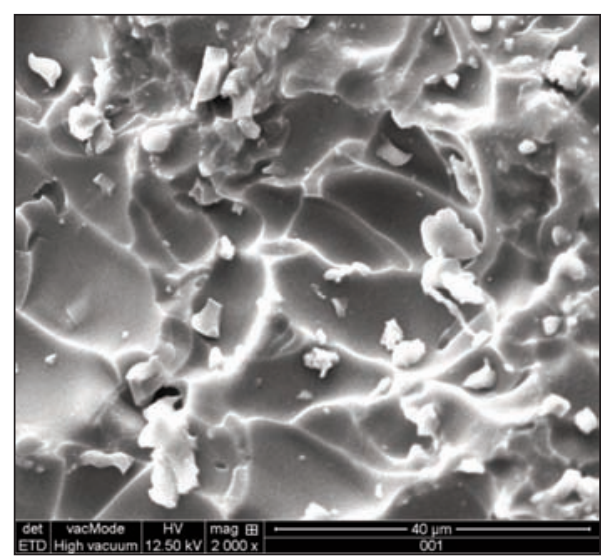

b

Fig. 5. SEM images of polyurethane composites: $a$ - the sem image for Micro-balloon; $b$ - the sem image for polyurethane resin

\section{CONCLUSION}

The low-velocity impact response of polyurethanebased warp-knitted spacer fabric composites have been evaluated under the impact velocity of $1 \mathrm{~m} / \mathrm{s}$ and $2 \mathrm{~m} / \mathrm{s}$, respectively.
Results show that the composites possess promising impact resistance performance due to their special structure, especially at the low-velocity range.

Furthermore, the impact resistance properties are significantly affected by the fabric surface structures and the types of Micro-balloon.

All the findings would offer helpful references on the optimization of structure parameters and property analysis of the polyur-

ethane resin composites.

\section{ACKNOWLEDGEMENT}

Authors acknowledge with the financial support by The Foundation of Inner Mongolia University Scientific Research Projects, NJZY18095.

\section{BIBLIOGRAPHY}

[1] Bogenfeld, R.M., Kreikemeier, J., Wille, T. An analytical scaling approach for low-velocity impact on composite structures. In: Composite Structures, 2018, 187(71):84.

[2] Shishevan, F.A., Akbulut, H., Mohtadi-Bonab, M.A. Erratum to: Low velocity impact behavior of basalt fiberreinforced polymer composites. In: Journal of Materials Engineering \& Performance, 2017, 26(8):1-1.

[3] He, W., Liu, J., Wang, S., et al. Low-velocity impact response and post-impact flexural behaviour of composite sandwich structures with corrugated cores. In: Composite Structures, 2018.

[4] Zhi, C., Long, H. Flexural properties of syntactic foam reinforced by warp knitted spacer fabric. In: Autex Research Journal, 2016, 16(2):57-66.

[5] Ahmadi, M.S., Dastan, T. Impact and flexural properties of hybrid jute/HTPET fibre reinforced epoxy composites. In: Indian Journal of Fibre \& Textile Research, 2017, 42(3):307-311.

[6] Velosa, J.C., Rana, S., Fangueiro, R., et al. Mechanical behavior of novel sandwich composite panels based on 3D-knitted spacer fabrics. In: Journal of Reinforced Plastics \& Composites, 2012, 31(2):95-105.

[7] Chen, S., Long, H., Liu, Y., et al. Mechanical properties of 3D-structure composites based on warp-knitted spacer fabrics. In: Autex Research Journal, 2015, 15(2):127-137.

[8] Mingxing, Zhang, Baozhong, Sun, Bohong, Gu. Dynamic behavior of 3D biaxial spacer weft-knitted composite t-beam under transverse impact. In: Mechanics of Composite Materials \& Structures, 2009, 16(5):356-370.

[9] Chen, S., Gao, X.P., Long, H.R. Preparation of polyurethane-based composites reinforced with warp-knitted spacer fabrics and their sound-absorption behaviors. In: Journal of Donghua University, 2016.

Authors:

\section{SI CHEN ${ }^{1}$, DA-WEI SHI ${ }^{1,2}$}

${ }^{1}$ College of Light Industry and Textile, Inner Mongolia University of Technology, Hohhot, China

${ }^{2}$ College of Textile, Tianjin Polytechnic University, Tianjin, China

Corresponding author:

SI CHEN

e-mail: ansn9119@126.com 